\author{
Asian Journal of \\ Medical and Biological Research \\ ISSN 2411-4472 (Print) 2412-5571 (Online) \\ www.ebupress.com/journal/ajmbr
}

\title{
Article \\ Comparison the effects of animal fat (ghee) with that of vegetable fat (dalda) in respect to hemato-biochemical parameters in mice
}

\author{
Md. Saidur Rahman ${ }^{1}$, Md. Mehedi Hasan ${ }^{2}$, Md. Ehsanul Kabir ${ }^{3}$, Nahid Nawrin Sultana ${ }^{4}$, Md. Eliusur Rahman
} Bhuiyan $^{1}$ and Nazim Ahmad ${ }^{1 *}$

${ }^{1}$ Department of Physiology, Bangladesh Agricultural University, Mymensingh, Bangladesh

${ }^{2}$ Department of Medicine, Bangladesh Agricultural University, Mymensingh, Bangladesh

${ }^{3}$ Department of Pathology, Bangladesh Agricultural University, Mymensingh, Bangladesh

${ }^{4}$ Department of Pharmacology, Bangladesh Agricultural University, Mymensingh, Bangladesh

${ }^{*}$ Corresponding author: Professor Dr. Nazim Ahmad, Department of Physiology, Bangladesh Agricultural University, Mymensingh, Bangladesh. Phone: +8801712410060; E-mail: abirshakir@yahoo.co.uk

Received: 07 June 2018/Accepted: 20 June 2018/ Published: 30 June 2018

\begin{abstract}
The experiment was conducted to compare the effects of animal fat (ghee) and vegetable fat (dalda) in respect to hemato-biochemical changes in mice. A total of twenty one, 45 days old (Swiss Albino) mice were randomly divided into three equal experimental groups as $\mathrm{A}, \mathrm{B}$ and $\mathrm{C}(\mathrm{n}=7)$. Group A was considered as control and fed only broiler pellet, group B was fed broiler pellet with ghee $(25 \mathrm{gm} / 1000 \mathrm{gm}$ feed $)$ and group C was fed broiler pellet with dalda ( $25 \mathrm{gm} / 1000 \mathrm{gm}$ feed) respectively. At day 40, all mice were sacrificed to collect blood for hematological parameters where blood profile was analyzed by biochemical tests. Total erythrocyte counts were significantly $(\mathrm{p}<0.05)$ higher in ghee and dalda supplemented mice $(B: 8.99 \pm .34$ million/cu. mm. and C: $8.27 \pm .43$ million/cu.mm.) compared to control group (A: 7.49 \pm .22 million/cu.mm.). The significantly $(\mathrm{P}<0.05)$ higher hemoglobin concentration was recorded in ghee supplemented group B $(9.02 \pm .18 \mathrm{gm} / \mathrm{dl})$ than other

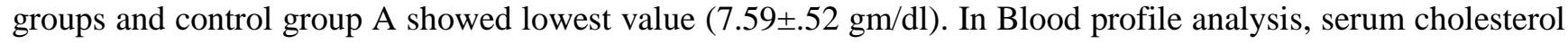
and HDL value were higher in ghee and dalda supplemented group than control group. On the other hand triglyceride value was significantly $(\mathrm{P}<0.05)$ lower in control group $(\mathrm{A}: 44 \pm 4.58 \mathrm{mg} / \mathrm{dl})$ than ghee and dalda supplemented group (B: $80.33 \pm 2.51 \mathrm{mg} / \mathrm{dl}, \mathrm{C}: 71.2 \pm 4.26 \mathrm{mg} / \mathrm{dl}$ ). The study suggests that ghee and dalda supplementation with regular diet would be able to significantly increase cholesterol and triglyceride in mice.
\end{abstract}

Keywords: biochemical test; blood profile; dalda; ghee; mice

\section{Introduction}

Mainly fat is used for a source of essential fatty acids and energy (Rahman et al., 2012). Dietary fats and oils are known as macronutrients as well as the main source of fat-soluble vitamins composed of saturated, monounsaturated and polyunsaturated fatty acids (Rezq et al., 2010). There is a portion of $60-70 \%$ saturated fat found in fatty acid analysis of ghee (Karandikar et al., 2016). Due to this high percentage of saturated fatty acids, it is concerned about the possibility of ghee contributing increased synthesis of cholesterol leading to increased risk of cardiovascular diseases (Sharma et al., 2010). On the other hand, monounsaturated and polyunsaturated fatty acids decrease the chances of coronary artery diseases by reducing the LDL cholesterol and total cholesterol (Basak et al., 2017). Long-chain saturated fatty acids enriched fatty foods may contribute to the accumulation of lipids in the body and these changes can be reduced by consumption of unsaturated fatty acids (Gondim et al., 2018).

Lipoproteins are closely related to the risk of cardiovascular diseases as follows: low-density lipoproteins (LDL) indicate an increased risk and high-density lipoproteins (HDL) are considered a protective factor (Aguila et al., 2002). One of the most important risk factors of developing cardiovascular diseases (CVD) and lipid 
abnormalities is hypercholesterolemia which is a lipoprotein metabolic disorder characterized by high serum low density lipoprotein and blood cholesterol (Akter et al., 2013).

Generally high-fat diets and diets high in saturated fats cause obesity and fatty livers in a number of different strains and species of rodents (Wiley and Weinheim, 2002). High fat or cholesterol western diets induce extreme hypercholesterolemia and also lead to decrease HDL levels and hypertriglyceridemia. Moreover, these diets generate pathologies independent of atherosclerosis such as changes in plasma lipids and dietary cholesterol increases the levels of hepatic and plasma triacylglycerols by reducing fatty acid oxidation (Islam et al., 2014). Chemically ghee (clarified butter) contains triglycerides mixture, particularly derived from fatty acids such as palmitic, oleic, myristic and stearic acids. Fats rich in saturated fatty acids may cause the elevation of plasma total and lipoprotein cholesterol. Changes in the diet in terms of fatty acid content have a remarkable effect on blood lipid profile. The information regarding the effects of ghee and dalda with high fat diet on cardiovascular and hepatic disease is limited (Ohlsson, 2010).

Traditionally in Bangladesh, people commonly use ghee and dalda to make foods more delicious and tasty. But as we know ghee and dalda contains high level of fatty acids that are responsible for cardiovascular diseases and obesity, it is necessary to investigate the marginal supplementation dose of these fats. There some study on heart diseases in man related with dyslipidemia or obesity were reported in Bangladesh (Zaman et al., 2007; Islam et al., 2002; Islam and Majumder, 2012) but there is scanty information on heart diseases of companion animals (i.e., dog, cat, etc.). As research on companion animals (dogs and cats) is difficult to carry out, the laboratory animals (mice) were selected as experimental model for this study. Therefore, the experiment was done to investigate the effects of ghee and dalda on hematological and biochemical profile of blood such total erythrocyte count (TEC), hemoglobin ( $\mathrm{Hb}$ ) concentration, total serum cholesterol, triglycerides and high density lipoprotein (HDL) of mice.

\section{Materials and Methods}

The experiment was conducted in the Department of Physiology, Bangladesh Agricultural University (BAU), Mymensingh.

\subsection{Ethical statement}

All mice were maintained in cages according to university animal care using their guidelines and the samples were collected by following the international standard considering animal welfare and ethics.

\subsection{Experimental animals}

In this study, 45 days aged twenty one Swiss Albino mice (Mus musculus) with an average body weight of $25 \pm 1$ gm were purchased from Pharmacy Department, Jahangirnagar University, Savar, Dhaka. Before the experiment the mice were adapted for 7 days for getting used to the environment.

\subsection{Experimental protocols and diet}

The mice were randomly divided into 3 equal groups $(n=7)$. Group A was considered as untreated control and fed on standard commercial broiler pellet. Mice of group B and C were fed on standard broiler pellet enriched with ghee (1000 gm: $25 \mathrm{gm})$ and dalda (1000 gm: $25 \mathrm{gm})$ respectively for a period of 40 days (16 October to 25 November, 2015). The diet was prepared on daily basis and supplied as $5 \mathrm{gm} / \mathrm{mouse} /$ day and fresh drinking water was supplied ad libitum in all groups. On day 40, blood samples were collected by a syringe directly from the heart by sacrificing the mice after an overnight fasting. Fresh blood was used for hematological studies and prepared serum for biochemical analysis.

\subsection{Hematological parameters}

Total erythrocyte count (TEC) and the hemoglobin estimation (acid-hematin method) was determined as described by Ghai (1999). The number of RBC was calculated as follows: \{(Number of RBC No. of cell counted $X 10000) \div 1000000\}$ and the result was expressed in million $/ \mathrm{mm}^{3}$. The result of hemoglobin concentration was expressed in $\mathrm{gm} / \mathrm{dl}$ or $\mathrm{gm} \%$.

\subsection{Biochemical studies}

The biochemical parameters were performed colorimetrically using Humalyzer 2000 (Human type, Germany) in collaboration with Biochemistry Department, BAU, Mymensingh. The total serum cholesterol and triglycerides were determined following the procedure described by Trinder and Ann (1969). After enzymatic hydrolysis and oxidation the results were expressed in $\mathrm{mg} / \mathrm{dl}$. Low-density lipoproteins (LDL and VLDL) and chylomicron 
fractions were precipitated quantitatively by the addition of phosphotungstic acid in presence of magnesium ions. After centrifugation, the cholesterol concentration in the HDL (high-density lipoprotein) fraction was determined which remained in the supernatant.

\subsection{Statistical analysis}

The hematological and biochemical parameters of mice corresponding to Animal fat (Ghee) \& Vegetable fat (Dalda) supplementation were compared by performing ANOVA (Analysis of Variance) by Steel and Torrie (1980).

\section{Results}

The animals consumed ghee and dalda enriched ration for 40 days and there some changes were found in their blood profile. Changes in total erythrocyte count and hemoglobin content in different groups of mice are presented in Table 1 . Total erythrocyte counts were significantly $(\mathrm{p}<0.05)$ higher in ghee supplemented group B $(8.99 \pm .34 \mathrm{million} / \mathrm{cu} . \mathrm{mm}$.) and dalda supplemented group C $(8.27 \pm .43 \mathrm{million} / \mathrm{cu} . \mathrm{mm}$.) compared to control group A $(7.49 \pm .22$ million/cu.mm.). Statistically significant $(\mathrm{P}<0.05)$ difference was also recorded in between ghee dalda supplemented mice. The highest hemoglobin concentration was observed in group B $(9.02 \pm 0.18$ $\mathrm{gm} / \mathrm{dl})$ followed by group C $(8.37 \pm 0.09 \mathrm{gm} / \mathrm{dl})$ and group A $(7.59 \pm 0.52 \mathrm{gm} / \mathrm{dl})$ in terms of significant $(\mathrm{P}<0.05)$ differences among the groups.

Table 1. Effects of ghee and dalda on hematological parameters (mean \pm SD) in mice $(n=7)$.

\begin{tabular}{llllll}
\hline $\begin{array}{l}\text { Hematological } \\
\text { parameters }\end{array}$ & \multicolumn{3}{c}{ Mean \pm SD } & P-value & Reference value $^{*}$ \\
\cline { 2 - 5 } & Group-A (Control) & Group-B (Ghee) & Group-C (Dalda) & \\
\hline $\mathrm{RBC}($ million/mm3) & $7.49 \pm .22^{\mathrm{c}}$ & $8.99 \pm .34^{\mathrm{a}}$ & $8.27 \pm .43^{\mathrm{b}}$ & 0.05 & $5-9.5$ \\
$\mathrm{Hb}(\mathrm{gm} \%)$ & $7.59 \pm .52^{\mathrm{c}}$ & $9.02 \pm .18^{\mathrm{a}}$ & $8.37 \pm .09^{\mathrm{b}}$ & 0.05 & $10.9-16.3$ \\
\hline
\end{tabular}

* Reference values are in accordance with Suckow et al. (2001). Values with different superscript letter in same row differ significantly $(\mathrm{P}<0.05)$.

The plasma lipid profiles regarding serum cholesterol, triglyceride and HDL are shown in Table 2. Total cholesterol levels were significantly $(\mathrm{P}<0.05)$ much higher in ghee supplemented group B $(157.3 \pm 4.51 \mathrm{mg} / \mathrm{dl})$ and dalda supplemented group C $(160 \pm 4.58 \mathrm{mg} / \mathrm{dl})$ comparatively with the lowest value in control group A $(133.67 \pm 3.05 \mathrm{mg} / \mathrm{dl})$. The values were statistically significant $(\mathrm{P}<0.05)$ among all three groups. Triglyceride concentration varies significantly $(\mathrm{P}<0.05)$ among the groups the value was lower in group A $(44 \pm 4.58 \mathrm{mg} / \mathrm{dl})$ compared to group B $(80.33 \pm 2.51 \mathrm{mg} / \mathrm{dl})$ and group $\mathrm{C}(71.2 \pm 4.26 \mathrm{mg} / \mathrm{dl})$. HDL values of group B $(65 \pm 1.75$ $\mathrm{mg} / \mathrm{dl})$ and $\mathrm{C}(58.1 \pm 1.80 \mathrm{mg} / \mathrm{dl})$ were obtained more than group A $(50.67 \pm 3.51 \mathrm{mg} / \mathrm{dl})$ whereas the values were not significant in the study.

Table 2. Effects of ghee and dalda on biochemical parameters (mean \pm SD) in mice $(n=7)$.

\begin{tabular}{llllll}
\hline $\begin{array}{l}\text { Biochemical } \\
\text { parameters }\end{array}$ & \multicolumn{1}{c}{ Mean \pm SD } & P-value & Reference value $^{*}$ \\
\cline { 2 - 5 } $\begin{array}{l}\text { Cholesterol } \\
(\mathrm{mg} / \mathrm{dl})\end{array}$ & $133.67 \pm 3.05^{\mathrm{c}}$ & $157.30 \pm 4.51^{\mathrm{a}}$ & $160.00 \pm 4.58^{\mathrm{b}}$ & 0.05 & $114 \pm 56.3$ \\
$\begin{array}{l}\text { Triglyceride } \\
(\mathrm{mg} / \mathrm{dl})\end{array}$ & $44.00 \pm 4.58^{\mathrm{c}}$ & $80.33 \pm 2.51^{\mathrm{a}}$ & $71.20 \pm 4.26^{\mathrm{b}}$ & 0.05 & $91 \pm 58$ \\
HDL $(\mathrm{mg} / \mathrm{dl})$ & $50.67 \pm 3.51^{\mathrm{a}}$ & $65.00 \pm 1.75^{\mathrm{a}}$ & $58.10 \pm 1.80^{\mathrm{a}}$ & 0.05 & $41.32 \pm 0.85$ \\
\hline
\end{tabular}

*Reference values are in accordance with Fox et al. (2002) and Basak et al. (2017). Values with different superscript letter in same row differ significantly $(\mathrm{P}<0.05)$.

\section{Discussion}

We have investigated the effects of fat from animal and vegetable origin on hematology and lipid profile in mice. Supplementation of ghee and dalda significantly increased total erythrocyte count and hemoglobin concentration in our study. The results are also similar to Ekanem and Yusuf (2008) found that there were significant increase in the hemoglobin concentration and red blood cell counts of fat treated mice when compared with the untreated. It is necessary to mention that in both researches, hematological studies were done by same type of hematologic analyzer. 
Supplementation of ghee and dalda increased total serum cholesterol significantly in this study. These results agreed with findings reported that palm and soybean oil (Hoque et al., 2018), high level of fish oil or fat in diet (Garg and Blake, 1997) increased the concentration of serum cholesterol. This result is also similar to Jeffery $e t$ al. (1996) observed that the serum total cholesterol concentrations raised in the animals fed the high-fat diets. In addition, some researchers demonstrated that hydrogenated vegetable fat (HVF) increased total blood cholesterol in mice (Estruch et al., 2006; Stender and Dyerberg, 2003). Significant increased concentration of cholesterol was also found in rats fed on diet enriched with soybean oil (Rasel et al., 2016). But Akter et al. (2013) and Rezq et al. (2010) stated that total cholesterol level was significantly higher in mice fed on animal fat diet compared with vegetable oil that is slightly contradicted with our study and that may be happened due to rearing the experimental mice for a long period.

The finding of increasing triglyceride supported by the study of Akter et al. (2013) who found that mice feed with ghee increased blood triglyceride level in mice at the age of 45 days and our research have done with the blood collected at the age of 40 days which are almost similar. This study also supported by Colandre et al. (2003) and Ibrahim et al. (2005) who showed that trans fatty acids increase triglyceride and more cholesterol was observed in the mice given animal fat. These results are in agreement with the study of Karanth and Jeevaratnam (2009) who found that intake of high fat diet significantly increased the plasma lipid profile including LDL but decrease HDL which is contradictory to our research. Some other findings also stated that animal and vegetable fat supplementation decrease HDL (Ibrahim et al., 2005; Estruch et al., 2006) but in this research, the measures of HDL values were insignificant among the mice groups which may reveal the same occurrence.

\section{Conclusions}

The research findings suggest that administration of ghee and dalda alter lipid profile as significant increased serum cholesterol and triglyceride. So, further investigation with large number of animals and more parameters will give precise information about the use of animal and vegetable fat as supplementation.

\section{Acknowledgements}

The authors would like to express their gratitude to the Department of Physiology, Bangladesh Agricultural University, Mymensingh, Bangladesh to execute this research work.

\section{Conflict of interest}

None to declare.

\section{References}

Aguila MB, CC Loureiro, ADR Pinheiro and CA Mandarim-de-Lacerda, 2002. Lipid metabolism in rats fed diets containing different types of lipids. Arq. Bras. Cardiol., 78: 32-8.

Akter S, MA Miah, MAHNA Khan and MK Islam, 2013. Effects of estrogen and folic acid on high fat induced hypercholesterolemic mice. Br. Biotechnol. J., 3: 39-53.

Basak A, LA Banu, N Ahmad and K Rafiq, 2017. Effect of sunflower oil supplementation in feed on body weight and hematobiochemical parameters in mice. Progress. Agric., 28: 36-41.

Colandre ME, RS Diez and CA Bernal, 2003. Metabolic effects of trans fatty acids on an experimental dietary model. Bri. J. Nutr., 89: 631-639.

Ekanem JT and OK Yusuf, 2008. Some biochemical and haematological effects of black seed (Nigella sativa) oil on Trypanosoma brucei infected rats. Afr. J. Biotechnol., 7: 153-157.

Estruch R, MA Martinez-Gonzalez, D Corella, J Salas-Salvado, V Ruiz-Gutierrez, MI Covas, M Fiol, E GomezGracia, MC Lopez-Sabater, E Vinyoles, F Aros, M Conde, C Lahoz, J Lapetra, G Saez and E Ros, 2006. Effects of a Mediterranean-style diet on cardiovascular risk factors: A randomized trial. Ann. Intern. Med., 145: 1-11.

Fox JG, LC Anderson, FM Loew and FW, 2002. Quimby. Laboratory Animal Medicine; $2^{\text {nd }}$ Edition, A volume in American College of Laboratory Animal Medicine.

Garg ML and R Blake, 1997. Cholesterol dynamics in rats fed diets containing either fish oil or sunflower oil. Nutr. Res., 17: 485-492.

Ghai CL, 1999. A text book of Practical Physiology; $7^{\text {th }}$ Edition, Jaypee Brothers Medical Publishers (p) Ltd, New Delhi. 1999.

Gondim PN, PV Rosa, D Okamura, VDO Silva, EF Andrade, DA Biihrer and LJ Pereira, 2018. Benefits of fish oil consumption over other sources of lipids on metabolic parameters in obese rats. Nutrients, 10: 65. 
Hoque MS, ME Kabir, MM Hasan, MT Rahman, M Rashid, T Ruba, MH Rahman, ABMJ Uddin and MM Hossain, 2018. Biochemical and pathological effects of palm, mustard and soybean oils in rats. Bangl. J. Vet. Med., 16: 107-114.

Ibrahim A, S Natrajan and R Ghafoorunissa, 2005. Dietary trans-fatty acids alter adipocyte plasma membrane fatty acid composition and insulin sensitivity in rats. Metabolism, 54: 240-246.

Islam AKMM and AAS Majumder, 2012. Hypertension in Bangladesh: A review. Indian Heart, 64(3): 319-323.

Islam K., N Ahmed, S Majumder, R Islam and MA Barek, 2002. Effect of dietary supplementation of soybean oil body weight certain haemato-biochemical parameters in broiler birds. Bangl. Vet. J., 36: 15-17.

Islam MS, MK Islam and SK Das, 2014. Effects of butter and estrogen on lipid profile and histotexure of liver and skin in reference to the development of obesity in Swiss Albino mice. Int. J. Innovation and Appl. Studies, 8: 71-85.

Jeffery NM, P Yaqoob, EA Kewsholme and PC Calder, 1996. The effects olive oil upon rat serum lipid levels and lymphocyte functions appear to be due to oleic acid. Ann. Nutr. Metab., 40: 71-80.

Karanth J and K Jeevaratnam, 2009. Effect of dietary lipid, carnitine and exercise on lipid profile in rat blood, liver and muscle. Indian J. Exp. Biol., 47: 748-753.

Karandikar YS, AS Bansude and EA Angadi, 2016. Comparison between the effect of cow ghee and butter on memory and lipid profile of Wistar rats. J. Clin. Diagn. Res., 10: 11-15.

Ohlsson L, 2010. Dairy products and plasma cholesterol levels. Food Nutr. Res., 54: 5124.

Rahman MA, M Jahan, S Karmaker and MK Islam, 2012. Effects of different fatty acid supplementation on body weight and haematobiochemical parameters in rat. Int. J. Nat. Sci., 2: 21-25.

Rasel IH, N Ahmad, MER Bhuiyan and MS Islam, 2016. Effects of edible oils on biochemical parameters of blood in mice. Int. J. Anim. Resour., 1: 27-34.

Rezq AA, FA Labib and AEM Attia, 2010. Effect of some dietary oils and fats on serum lipid profile, calcium absorption and bone mineralization in mice. Pak. J. Nutr., 9: 643-650.

Sharma H, X Zhang and C Dwivedi, 2010. The effect of ghee (clarified butter) on serum lipid levels and microsomal lipid peroxidation. AYU, 31: 134-140.

Spiteller G, 2007. The important role of lipid peroxidation processes in aging and age dependent diseases. Mol. Biotechnol., 37: 5-12.

Steel RGD and JH Torrie, 1980. Principles and procedures of statistics. A Biometrical Approach. $2^{\text {nd }}$ edition. McGraw Hill, New York, USA, 96-97, 106-107, 144, 173-175.

Stender S and J Dyerberg, 2003. The influence of trans fatty acids on health. The Danish Nutrition Council Publication, 34.

Suckow MA, P Danneman and C Brayton, 2001. The Laboratory Mouse. A Volume in the Laboratory Animal Pocket Reference Series.

Trinder P and T Ann, 1969. Oral effect on Lactobacilli bacteria. Int. J. Food Microbiol., 41: 33-42.

Wiley HF and TD Weinheim, 2002. Serum and liver lipids of rats fed cocoa butter, corn oil, palm kernel oil, coconut oil and cholesterol. Nutr. Res., 8: 287-294.

Zaman MM, J Ahemd, SR Choudhury, SM Numan, K Parvin and MS Islam, 2007. Prevalence of ischemic heart disease in a rural population of Bangladesh. Indian Heart J., 59: 239-241. 